\title{
Children recovered from malnutrition exhibit normal insulin production and sensitivity
}

\author{
Vinicius J. B. Martins ${ }^{1,2 *}$, Paula A. Martins ${ }^{1}$, Janaína das Neves ${ }^{1}$ and Ana L. Sawaya ${ }^{1}$ \\ ${ }^{1}$ Department of Physiology, Federal University of São Paulo, São Paulo, Brazil \\ ${ }^{2}$ Rua Botucatu, 862, $2^{\circ}$ andar, Ed. Ciências Biomédicas, São Paulo, CEP: 04023-060, Brazil \\ (Received 19 January 2007 - Revised 7 June 2007 - Accepted 19 June 2007)
}

Protein-energy malnutrition promotes adaptive hormonal changes that result in stunting. A previous study showed that stunted children had increased insulin sensitivity and diminished pancreatic $\beta$-cell function. The objectives of the present study were to analyse the glucose, insulin, homeostasis model assessment of insulin sensitivity (HOMA-S) and homeostasis model assessment of pancreatic $\beta$-cell function (HOMA-B) levels after nutritional recovery. The recovered group $(n$ 62) consisted of malnourished children after treatment at a nutrition rehabilitation centre. At the beginning of treatment their age was 2.41 (SD 1.28) and 2.31 (SD 1.08) years, weight-for-age $Z$ score -2.09 (SD 0.94 ) and -2.05 (SD 0.55 ) and height-for-age $Z$ score -1.85 (SD 1.11) and -1.56 (SD 0.90), for boys and girls respectively. The control group consisted of well-nourished children without treatment $(n$ 26). After treatment, boys of the recovered group gained 1.29 (SD 1.06) $Z$ scores of height-for-age and 1.14 (SD 0.99 ) $Z$ scores of weight-for-age, and girls, 1.12 (SD 0.91 ) and 1.21 (SD 0.74) $Z$ scores respectively. No differences were found between control and recovered groups in insulin levels for boys $(P=0.704)$ and girls $(P=0.408)$, HOMA-B for boys $(P=0.451)$ and girls $(P=0.330)$, and HOMA-S $(P=0.765)$ for boys and girls $(P=0.456)$ respectively. The present study shows that the changes observed previously in glucose metabolism and insulin were reverted in children who received adequate treatment at nutritional rehabilitation centres and showed linear catch-up.

Stunting: Nutritional recovery: Insulin sensitivity: Homeostasis model assessment

Malnutrition is still a public health problem of high prevalence in many parts of the world ${ }^{1}$, leading to stunting when it occurs chronically during childhood ${ }^{2}$. In developing countries, stunting is associated with intra-uterine and maternal malnutrition, inadequate quality or quantity of complementary foods during infancy, impaired absorption of nutrients caused by intestinal infections and parasites or a combination of these factors ${ }^{3}$.

The long-term consequences of childhood malnutrition have been associated with metabolic changes that may contribute to the onset of non-communicable diseases ${ }^{4}$. Even though studies on the consequences of postnatal malnutrition are scarce, a study done by González-Barranco et $a l^{5}$ concluded that regardless of birth weight, malnutrition has adverse effects on insulin metabolism and glucose tolerance in young men.

A series of studies in Brazil identified alterations in body composition associated with stunting among adolescents. Stunted girls living in slums were found to be more susceptible to weight-for-height gain when compared with a control group when consuming fat-rich diets, increasing the risk of developing obesity ${ }^{6}$. Martins et al. $^{7}$ in a prospective study of 11-15-year-old adolescents observed that stunted girls gained less lean mass and had a significantly higher increase of fat mass at follow up. A recent study with the same adolescents found a lower concentration of fasting insulin in the stunted group compared with the control group. The stunted group also presented a lower value of homeostasis model assessment of pancreatic $\beta$-cell function (HOMA-B) and an increased value of homeostasis model assessment of insulin sensitivity (HOMA-S) when compared with the control group. These findings indicate lower activity of pancreatic $\beta$ cells as well as increased insulin sensitivity in these stunted adolescents ${ }^{8}$.

In a study with children treated at the Nutrition Education and Recovery Center (CREN; São Paulo, Brazil), das Neves et al. ${ }^{9}$ showed that children who recovered from malnutrition had a higher height-for-age gain in $Z$ score when compared with the weight-for-age index. The treated groups also presented a lower amount of fat mass when compared with the control group, after treatment at CREN. However, the study did not investigate if the height recovery was also capable of normalising insulin-related parameters.

Studies on anthropometric recovery in malnourished children and reversion of the change in glucose metabolism are almost non-existent; therefore the present study aimed to analyse insulin resistance and pancreatic $\beta$-cell function in children and adolescents who recovered from malnutrition at CREN.

Abbreviations: CREN, Nutrition Education and Recovery Center; HOMA-B, homeostasis model assessment of pancreatic $\beta$-cell function; HOMA-S, homeostasis model assessment of insulin sensitivity.

* Corresponding author: Dr Vinicius José Baccin Martins, fax +55 115576 4275, email vifisio@ecb.epm.br 


\section{Methods}

\section{Nutrition Education and Recovery Center}

The recovered children of the present study were treated at CREN, a centre that offers treatment to slum children with mild to severe malnutrition. Paediatricians, nutritionists, social workers and psychologists participated in the treatment. The paediatrician monitored the clinical status, laboratory findings and anthropometric progress of each child. The nutritionist followed the child's diet and corrected the problems identified during treatment. Laboratory tests (blood and stools) were done each semester. The children also received Fe and vitamin (A, B, C and D) supplements in prophylactic doses $^{9}$.

\section{Protocol}

The children were selected from CREN's database and from an anthropometric census carried out in slums in the southern area of the city of São Paulo. In order to be included in the study, the children were submitted to a screening procedure. Stool and parasite examinations were done and urine samples were collected to check for urinary infection, or presence of glucose, epithelial cells and leucocytes. Blood tests were also done to determine if the child had anaemia. The children were treated before the study, if any of these examinations were positive.

Sixty-two children recovered from malnutrition and twentysix children from the community were included in the study. These children were divided into two groups according to the following criteria: (1) the treated group, consisting of children treated at CREN who recovered from malnutrition and whose $Z$ score in the first visit was below -1.645 (5th percentile) for weight-for-age or height-for-age (thirty-one boys and thirty-one girls); (2) the control group, consisting of children whose $Z$ score for weight-for-age and height-forage were above -1.5 (sixteen boys and ten girls) and whose socio-economic conditions were the same as those of the children in the treated group.

The children in the recovered group were followed up from the first visit, when they began treatment at CREN, until the protocol of the study was done, characterising a follow-up time of approximately 60 months. The children in the control group were selected based on anthropometric assessments done directly at the slums.

The children of the recovered group were admitted at CREN between 1994 and 2002. Data were collected from October 2001 to March 2004. All families signed the Free and Informed Consent form and the study was approved by Research Ethics Committee of the Federal University of São Paulo.

\section{Anthropometry}

The children were weighed in underwear and asked to position themselves in a manner that their weight was equally distributed on both sides of the scale ${ }^{10}$. For children up to 7 years old, a digital scale with a capacity of $31 \mathrm{~kg}$ and precision of $10 \mathrm{~g}$ was used. Children above 7 years and adolescents were weighed on a platform scale with a capacity of $150 \mathrm{~kg}$ and precision of $50 \mathrm{~g}$ (model SD-150; Country Technologies, Gay Mills, WI, USA).

Height was determined with a stadiometer fixed to a wall with a precision of $0 \cdot 1 \mathrm{~cm}$. The children and adolescents were barefoot with ankles touching the wall, arms hanging loosely and head in the Frankfort plane ${ }^{10}$.

The program Epi Info 2000 (version 1.1.2a; Centers for Disease Control and Prevention, Atlanta, GA, USA) was used to assess nutritional status. The nutritional status indicators used were the $Z$ scores for weight-for-age, height-forage and weight-for-height, BMI and BMI $Z$ score using the National Center for Health Statistics ${ }^{11}$ curves as standard.

\section{Pubertal staging}

Pubertal stage was assessed by a physician at CREN using Tanner's criteria ${ }^{12}$. The children were then classified according to the cut-off values established by the $\mathrm{WHO}^{13}$; girls with breast stage equal to or greater than 2 (M2) were considered pubertal and boys with genital stage equal to or greater than 3 (G3) were considered pubertal; the children whose breasts or genitals were below these levels were considered prepubertal.

\section{Laboratory tests}

Blood was collected by an auxiliary nurse at CREN's research facility between 07.30 and 08.30 hours, after a $10 \mathrm{~h}$ fast, to assess insulin and glucose; then the samples were centrifuged and stored at $-20^{\circ} \mathrm{C}$. The analyses were done at the AFIP laboratory, at the Federal University of São Paulo. Insulin was determined by enzyme immunoassay (Tosoh Corporation, Tokyo, Japan) and glucose was analysed by the enzymic colorimetric method (Bayer Diagnostics, New York, NY, USA) using ADVIA equipment with a wavelength reading of $340 \mathrm{~nm}$.

A computer model was used to determine HOMA-S and HOMA-B from fasting plasma glucose and specific insulin, total insulin or C-peptide concentration ${ }^{14}$.

HOMA was validated by a series of studies $^{15,16}$ that also included non-diabetic children and adolescents ${ }^{17}$.

\section{Dietary intake}

An interviewer visited the families in their homes on three separate days (including a weekend day) to fill out the dietary questionnaire and determine the child's food intake during a $24 \mathrm{~h}$ period. These visits occurred in the same week in which the anthropometric evaluation was performed. The energy content and composition of the diet were calculated using a computer program specially designed for Brazilian food $^{18}$ and a Brazilian food composition table ${ }^{19}$.

\section{Statistical analysis}

The Mann-Whitney test was used for the statistical analysis of nutritional status. Fasting insulin results were compared with analysis of covariance using the insulin neperian logarithm to normalise the data. The results were adjusted for age and pubertal stage and these variables were included in the analysis of covariance model. The HOMA-B and HOMA-S 
indices were also analysed using analysis of covariance, and then corrected for pubertal stage and age. All the analyses were subject to variance homogeneity tests between the groups compared through the Levine test and the results of all of them were $P>0.05$. Furthermore, the interaction term between groups and interaction tests between groups and the model factors were analysed in each model and the result obtained was of $P>0.05$ for all of them. The software SPSS 11.0 for Windows (SPSS Inc., Chicago, IL, USA) was used for all the analyses having $\alpha=0 \cdot 05$.

\section{Results}

\section{Nutritional status at the beginning of treatment}

Following $\mathrm{WHO}^{13}$ criteria, the number of boys with mild malnutrition, according to the height-for-age and weight-for-age indices, was fourteen $(48 \%)$ and thirteen $(43 \%)$ respectively; the number with moderate or severe malnutrition was ten (34\% by height-for-age) and fifteen ( $50 \%$ by weight-forage). The number of girls with mild malnutrition was fourteen (50\% by height-for-age) and thirteen ( $41 \%$ by weight-forage); the number with moderate or severe malnutrition was seven ( $25 \%$ by height-for-age) and seventeen (54\% by weight-for-age). None of the studied children had oedema or hypoalbuminaemia.

\section{Nutritional recovery}

Table 1 shows the anthropometric data and nutritional status of the children recovered from malnutrition and controls. The malnourished children treated at CREN were on average 2.5 years old at the beginning of treatment. At the time of the present study, the recovered group showed values for weight-for-age, height-for-age, BMI, and BMI $Z$ score that were at the lower end but within the limit of normality for both sexes. Recovery children, however, showed significantly lower anthropometric values than control children.

\section{Pubertal stages}

Table 2 shows the pubertal stage data for boys and girls. None of the boys in the control group had reached puberty at the time of the study, whereas one boy in the recovered group reached puberty at this time. Four girls in the control group and five girls of the recovered group had reached puberty at the time of the study. Differences in pubertal stages were not significant between control and recovered groups.

\section{Food intake}

Table 3 shows the intake of macronutrients by the control and recovered groups. Intakes of protein of the recovered group were significantly higher than those of the control group.

\section{Insulin and homeostasis model assessment}

The results of plasma insulin concentration between the recovered and control groups and for both sexes are in Table 4. The mean concentration of plasma insulin adjusted for age and pubertal stage did not differ statistically between the control and recovered groups for boys $(P=0.704)$ and girls $(P=0.408)$. There was also no significant difference in glucose concentration ( $P=0.290$ and $P=0.507$ for boys and girls respectively). The control and recovered groups did not present a significant difference in HOMA-B ( $P=0.451$ for boys and $P=0.330$ for girls). The results were also similar for the HOMA-S index $(P=0.765$ for boys and $P=0.456$ for girls).

Table 1. Anthropometric variables and nutritional status for boys and girls at baseline and end of follow up, for the control and recovered groups

(Mean values and standard deviations)

\begin{tabular}{|c|c|c|c|c|c|c|c|c|}
\hline & \multicolumn{4}{|c|}{ Boys } & \multicolumn{4}{|c|}{ Girls } \\
\hline & \multicolumn{2}{|c|}{ Control (n 16) } & \multicolumn{2}{|c|}{ Recovered (n 31) } & \multicolumn{2}{|c|}{ Control (n 10) } & \multicolumn{2}{|c|}{ Recovered ( $n$ 31) } \\
\hline & Mean & SD & Mean & SD & Mean & SD & Mean & SD \\
\hline \multicolumn{9}{|l|}{ Baseline } \\
\hline Age (years) & - & - & $2 \cdot 41$ & $1 \cdot 28$ & - & - & $2 \cdot 31$ & 1.08 \\
\hline Weight-for-age ( $Z$ score) & - & - & -2.09 & 0.94 & - & - & -2.05 & 0.55 \\
\hline Height-for-age ( $Z$ score) & - & - & -1.85 & $1 \cdot 11$ & - & - & -1.56 & 0.90 \\
\hline BMI $\left(\mathrm{kg} / \mathrm{m}^{2}\right)$ & - & - & $15 \cdot 25$ & 1.39 & - & - & $14 \cdot 88$ & 1.41 \\
\hline BMI-for-age ( $Z$ score) & - & - & -0.84 & $1 \cdot 31$ & - & - & -0.87 & $1 \cdot 26$ \\
\hline \multicolumn{9}{|l|}{ Follow-up } \\
\hline Time elapsed (months) & - & - & $62 \cdot 39$ & $22 \cdot 04$ & - & - & $59 \cdot 51$ & $25 \cdot 37$ \\
\hline Age (years) & $8 \cdot 12$ & $2 \cdot 17$ & $7 \cdot 83$ & $2 \cdot 16$ & $8 \cdot 64$ & $2 \cdot 60$ & $7 \cdot 36$ & $2 \cdot 36$ \\
\hline Weight-for-age ( $Z$ score) & 0.70 & 0.43 & $-0.96^{*}$ & 0.56 & 0.62 & 0.41 & $-0.84^{\star}$ & 0.73 \\
\hline Height-for-age ( $Z$ score) & 0.63 & 0.60 & $-0.55^{\star}$ & 0.86 & $0 \cdot 88$ & 0.84 & $-0.43^{\star}$ & 0.85 \\
\hline BMI $\left(\mathrm{kg} / \mathrm{m}^{2}\right)$ & $17 \cdot 20$ & 1.83 & $14 \cdot 76^{\star}$ & $1 \cdot 29$ & $17 \cdot 12$ & 1.41 & $14 \cdot 82^{*}$ & 1.87 \\
\hline BMI-for-age (Z- score) & 0.49 & 0.76 & $-1 \cdot 06^{\star}$ & $1 \cdot 16$ & 0.34 & 0.44 & $-0.96^{*}$ & $1 \cdot 25$ \\
\hline \multicolumn{9}{|l|}{ Changes during treatment } \\
\hline Weight-for-age ( $Z$ score) & - & - & $1 \cdot 14$ & 0.99 & - & - & $1 \cdot 21$ & 0.74 \\
\hline Height-for-age ( $Z$ score) & - & - & 1.29 & 1.06 & - & - & $1 \cdot 12$ & 0.91 \\
\hline BMI $\left(\mathrm{kg} / \mathrm{m}^{2}\right)$ & - & - & -0.32 & $1 \cdot 37$ & - & - & 0.22 & 1.40 \\
\hline BMI-for-age ( $Z$ score) & - & - & -0.11 & 1.01 & - & - & -0.02 & 0.87 \\
\hline
\end{tabular}

*Mean value is significantly different from that of the control group of the same sex $(P<0.05$; Mann-Whitney test). 
Table 2. Pubertal staging at the end of the study

\begin{tabular}{|c|c|c|c|c|c|c|c|c|c|c|}
\hline & \multicolumn{4}{|c|}{ Boys } & \multirow[b]{3}{*}{$P^{*}$} & \multicolumn{4}{|c|}{ Girls } & \multirow[b]{3}{*}{$P^{*}$} \\
\hline & \multicolumn{2}{|c|}{ Control } & \multicolumn{2}{|c|}{ Recovered } & & \multicolumn{2}{|c|}{ Control } & \multicolumn{2}{|c|}{ Recovered } & \\
\hline & $n$ & $\%$ & $n$ & $\%$ & & $n$ & $\%$ & $n$ & $\%$ & \\
\hline Pre-pubertal & 15 & 100 & 30 & 96.8 & $<0.674$ & 6 & 60 & 26 & 83.9 & $<0.127$ \\
\hline Pubertal & 0 & 0 & 1 & $3 \cdot 2$ & & 4 & 40 & 5 & $16 \cdot 1$ & \\
\hline
\end{tabular}

${ }^{*}$ Fisher's exact test.

Table 3. Intake of macronutrients by the control and recovered groups for both sexes

(Mean values and standard deviations)

\begin{tabular}{|c|c|c|c|c|c|}
\hline & \multicolumn{2}{|c|}{ Control (n 26) } & \multicolumn{2}{|c|}{$\begin{array}{l}\text { Recovered } \\
\quad(n 62)\end{array}$} & \multirow[b]{2}{*}{$P$} \\
\hline & Mean & SD & Mean & SD & \\
\hline $\begin{array}{l}\text { Energy (kJ/kg } \\
\text { body weight) }\end{array}$ & $218 \cdot 18$ & $76 \cdot 40$ & $232 \cdot 98$ & $80 \cdot 40$ & 0.580 \\
\hline $\begin{array}{l}\text { Protein ( } \mathrm{g} / \mathrm{kg} \\
\text { body weight) }\end{array}$ & 1.67 & 0.69 & $2.09^{*}$ & 0.72 & 0.017 \\
\hline $\begin{array}{l}\text { Lipids ( } \mathrm{g} / \mathrm{kg} \\
\text { body weight) }\end{array}$ & $1 \cdot 20$ & 0.59 & $1 \cdot 35$ & 0.59 & 0.282 \\
\hline $\begin{array}{l}\text { Carbohydrates } \\
\text { (g/kg body weight) }\end{array}$ & $8 \cdot 1$ & 2.5 & $8 \cdot 2$ & $3 \cdot 18$ & 0.663 \\
\hline
\end{tabular}
Mann-Whitney test).

\section{Discussion}

The results of the present study show the importance of an adequate nutritional treatment in nutritional rehabilitation centres such as CREN. The recovered group, consisting of children who were treated in their early years of life $(0-6$ years), showed insulin and insulin sensitivity values similar to the control group (well fed) when corrected for age and pubertal stage at the end of follow up. These findings can be explained by the treatment offered at CREN, which consists of a balanced diet with protein of high biological value, nutrition education and medication for parasites, infections and anaemia. In addition, children and parents receive nutrition education, which is an important source of information on what has to be consumed in terms of food in order to recover nutritionally and develop healthier life habits.

It is known that differences in insulin and other hormone secretion occur among different types of malnutrition ${ }^{20}$. The type of malnutrition in Brazil, however, is essentially marasmus, related to insufficient food intake and high prevalence of infectious diseases, rather than kwashiorkor ${ }^{21}$. Confirming this, a recent national survey has shown that the percentage of proteins in Brazilian food is adequate ${ }^{22}$. That is probably the reason why we do not find oedema or severe hypoalbuminaemia in our malnourished children.

According to Kabir et al. ${ }^{23}$, protein is a key determinant of height gain. In their study a group of school-aged children received a protein-rich diet and another group had oil added to the diet. The group fed the protein-rich diet gained height in direct proportion to the amount of protein they received while the group that received the oil-rich diet displayed no additional growth.

The biological variable with one of the greatest long-term impact on the health of malnourished children after recovery from malnutrition is height gain. Special attention to diet is important during nutritional recovery, as it must allow a gain in height without offering excess energy as this would lead to obesity later on ${ }^{24}$. The data regarding food intake in Table 3 show that the group who recovered from malnutrition had a better protein intake than the control group. This can be justified by the fact that CREN aims also at nutrition education. The food intake results of the present study revealed that a healthier diet was maintained after discharge, despite their living conditions. On the other hand, the food intake data of the control group showed that those children had never received nutrition education and, as they live in slums, they may have been consuming inadequate foods.

Table 4. Insulin, homeostasis model assessment of pancreatic $\beta$-cell function (HOMA-B), homeostasis model assessment of insulin sensitivity (HOMA-S) and glucose concentration for boys and girls in the control and recovered groups

(Mean values with their standard errors)

\begin{tabular}{|c|c|c|c|c|c|c|c|c|c|c|c|c|c|c|}
\hline & \multicolumn{6}{|c|}{ Boys } & \multirow{2}{*}{$P \dagger$} & \multicolumn{6}{|c|}{ Girls } & \multirow{2}{*}{$P \dagger$} \\
\hline & \multicolumn{3}{|c|}{ Control } & \multicolumn{3}{|c|}{ Recovered } & & \multicolumn{3}{|c|}{ Control } & \multicolumn{3}{|c|}{ Recovered } & \\
\hline Insulin (pmol/l)* & 15 & 3.62 & 0.40 & 28 & $3 \cdot 76$ & 0.28 & NS & 9 & 3.78 & 0.26 & 30 & 3.52 & 0.09 & NS \\
\hline Glucose (mg/l) & 15 & $789 \cdot 0$ & $59 \cdot 2$ & 27 & $732 \cdot 8$ & $42 \cdot 3$ & NS & 9 & 755.4 & $43 \cdot 8$ & 29 & $790 \cdot 4$ & $16 \cdot 5$ & NS \\
\hline HOMA-B $(\%)^{*}$ & 15 & 4.71 & 0.308 & 27 & 4.92 & 0.220 & NS & 9 & 4.84 & 0.206 & 29 & 4.59 & 0.076 & NS \\
\hline
\end{tabular}

NS, $P>0.05$.

* Logarithmically transformed.

†From analysis of covariance with means adjusted for age and pubertal stage. 
The present results also show adequate $\beta$-cell function in children who recovered from malnutrition, contrary to the results found by Martins \& Sawaya ${ }^{8}$, who studied untreated stunted children of the same population of children living in slums in the city of São Paulo.

Literature data on anthropometric recovery and insulin normalisation are scarce. Soliman ${ }^{25}$ studied the concentration of fasting insulin in response to the infusion of arginine in children with marasmus, kwashiorkor and marasmic-kwashiorkor before and after nutritional rehabilitation in a hospital. After nutritional rehabilitation there were no differences between the insulin responses to arginine infusion of the kwashiorkor or marasmic-kwashiorkor groups and the response of the control group. This means that nutritional rehabilitation can have a positive influence on the response of the $\beta$-cell regarding insulin secretion and maintenance of glucose homeostasis.

Furthermore, the fetal and postnatal periods are critical to the development of the $\beta$-cell and maturation of pancreatic function. For this reason, intervention in the first years of life can justify the findings of the present study in regards to the insulin levels, given that the postnatal environmental factors exert an important role in $\beta$-cell maturation ${ }^{26}$. Soto et $a .^{27}$ studied changes in insulin sensitivity and secretion associated with low birth weight and postnatal growth in small-for-gestational-age newborns at age $48 \mathrm{~h}$ and after 1 year of life. After the first year of life, insulin sensitivity was more related to weight gain while insulin secretion was more related to length gain.

In the present study we found a lower BMI in recovered children compared with controls after an average of 5 years of follow up. We do not have a complete explanation for this finding. We believe this finding could be associated with diet quality, with the consumption of protein of higher biological value and the systematic treatment of infectious diseases and anaemia. However, we do not know why the bodies of these children prefer to gain more height rather than weight. Gain of lean mass is important to prevent obesity and its consequences, and favours the normal insulin and glucose homeostasis found.

In conclusion, the children recovered from malnutrition treated at CREN presented normal values for insulin and glucose metabolism. However, the present study included only prepubertal children, and therefore there is no assurance that these values continue to be normal in adult life.

\section{Acknowledgements}

We thank FAPESP (Fundação de Amparo à Pesquisa do Estado de São Paulo) for its sponsorship.

\section{References}

1. Sedgh G, Herrera GM, Nestel P, El Amin A \& Fawzi WW (2000) Dietary vitamin A intake and nondietary factors are associated with reversal of stunting in children. J Nutr 130, 2520-2526.

2. Golden MHN (1994) Is complete catch-up possible for stunted malnourished children? Eur J Clin Nutr 48, Suppl., S58-S71.

3. Allen LH \& Gillespie SR (2001) Improving child growth. In What Works? A Review of the Efficacy and Effectiveness of Nutrition Interventions. United Nations Administrative Committee on Coordinator/Sub-Committee on Nutrition $(\mathrm{ACC} / \mathrm{SCN})$ in collaboration with the Asian Development Bank, pp. 23-41. Manila and Geneva: United Nations University Press.

4. Moore SE, Halsall I, Howarth D, Poskitt EM \& Prentice AM (2001) Glucose, insulin and lipid metabolism in rural Gambians exposed to early malnutrition. Diabet Med 18, 646-653.

5. González-Barranco J, Rios-Torres JM, Castillo-Martinez L, Lopez-Alvarenga JC, Aguilar-Salinas CA, Bouchard C, Deprès JP \& Tremblay A (2003) Effect of malnutrition during the first year of life on adult plasma insulin and glucose tolerance. Metabolism 52, 1005-1011.

6. Sawaya AL, Grillo LP, Verreschi I, Silva AC \& Roberts SB (1998) Mild stunting is associated with higher susceptibility to the effects of high fat diets: studies in a shantytown population in São Paulo, Brazil. J Nutr 128, 415S-420S.

7. Martins PA, Hoffman DJ, Fernandes MTB, Nascimento CR, Roberts SB, Sesso R \& Sawaya AL (2004) Stunted children gain less lean body mass and more fat mass than their nonstunted counterparts: a prospective study. Br J Nutr 92, 819-825.

8. Martins PA \& Sawaya AL (2006) Evidence for impaired insulin production and higher sensitivity in stunted children living in slums. Br J Nutr 95, 996-1001.

9. das Neves J, Martins PA, Sesso R \& Sawaya AL (2006) Malnourished children treated in day-hospital or outpatient clinics exhibit linear catch-up growth and normal body composition. J Nutr 136, 648-655.

10. Lohman TG (1988) Skinfolds and body density and their relation to body fatness: a review. Hum Biol 53, 181-225.

11. Centers for Disease Control (2000) CDC growth charts http:// www.cdc.gov/growthcharts/ (accessed October 2005).

12. Tanner JM (1962) The development of the reproductive system. In Growth at Adolescence, 2nd ed., pp. 28-39 [JM Tanner, editor]. Oxford: Blackwell Scientific Publications.

13. Word Health Organization (1995) Physical Status: The Use and Interpretation of Anthropometry. Infants and Children. Technical Report Series no. 854. Geneva: WHO.

14. Wallace TM, Levy JC \& Matthews DR (2004) Use and abuse of HOMA modeling. Diabetes Care 27, 1487-1495.

15. Yokoyama H, Emoto M, Fujiwara S, et al. (2004) Quantitative insulin sensitivity check index and the reciprocal index of the homeostasis model assessment are useful indexes of insulin resistance in type 2 diabetic patients with wide range of fasting plasma glucose. J Clin Endocrinol Metab 89, $1481-1484$

16. Bonora E, Targher G, Alberiche M, Bonadonna RC, Saggiani F, Zenere MB, Monauni T \& Muggeo M (2000) Homeostasis model assessment closely mirrors the glucose clamp technique in the assessment of insulin sensitivity: studies in subjects with various degrees of glucose tolerance and insulin sensivity. Diabetes Care 23, 57-63.

17. Gungor N, Saad R, Janosky J \& Arslanian S (2004) Validation of surrogate estimates of insulin sensitivity and insulin secretion in children and adolescents. $J$ Pediatr 144, 47-55.

18. Federal University of São Paulo School of Medicine (1995) Programa de Apoio à Nutrição - NutWin (Programme for Nutrition Support; in Portuguese) http://www.unifesp.br/dis/ produtos/nutwin/index.htm

19. Núcleo de Estudos e Pesquisas em Alimentação (2004) TACO. Tabela Brasileira de Composição de Alimentos (Brazilian Food Composition Table) http//:www.unicamp.br/nepa/taco

20. Wartelow JC (1992) Endocrine changes in severe PEM. In Protein Energy Malnutrition, 1st ed., pp. 112-125. London: Edward Arnold.

21. Monteiro CA \& Benício MHD (1981) Epidemiologia da desnutrição protéico calórica (Epidemiology of protein calorie malnutrition). In Desnutrição Intra-uterina e Pós-natal, 1st ed., pp. 120-130 [FJ Nóbrega, editor]. São Paulo: Panamed Editorial LTDA. 
22. Instituto Brasileiro de Geografia e Estatística (2004) Pesquisa de Orçamentos Familiares - Analíse da Disponibilidade Domiciliar de Alimentos e do Estado Nutricional no Brasil. Rio de Janeiro: IBGE.

23. Kabir I, Rahman MM, Haider R, Mazumder RN, Khaled MA \& Mahalabanis D (1998) Increased height gain of children fed a high-protein diet during convalescence from shigellosis: a sixmonth follow-up study. J Nutr 128, 1688-1691.

24. Weisstaub GS \& Araya QM (2003) Recuperación nutricional: un desafío pendiente (Nutritional recovery: a pending challenge). Rev Méd Chile 131, 213-219.

25. Soliman AT, Hassan AW, Aref MK, Hintz AR, Rosenfeld RG \& Rogol AD (1986) Serum insulin-like growth fators I and II concentrations and growth hormone and insulin responses to arginine infusion in children with protein-energy malnutrition before and after nutritional rehabilitation. Pediatr Res 20, 1122-1130.

26. Martín MA, Fernández E, Pascual-Leone AM, Escrivá F \& Alvarez C (2004) Protein calorie restriction has opposite effects on glucose metabolism and insulin gene expression in fetal and adult rat endocrine pancreas. Am J Physiol Endocrinol Metab 286, E542-E550.

27. Soto N, Bazaes RA, Peña V, Salazar T, Ávila A, Iñiguez G, Ong KK, Dunger DB \& Mericq V (2003) Insulin sensivity and secretion are related to catch-up growth in small-for-gestational-age infants at age 1 year: results from a prospective cohort. J Clin Endocrinol Metab 88, 3645-3650. 